\title{
Taxation and Income Inequality in Nigeria
}

\author{
John Obiora Anyaduba ${ }^{1} \&$ Praise Oghenefejiro Otulugbu ${ }^{1}$ \\ ${ }^{1}$ Department of Accounting, Faculty of Management Sciences, University of Benin, Nigeria. \\ Correspondence: John Obiora Anyaduba, Department of Accounting, Faculty of Management Sciences, University \\ of Benin, Nigeria. E-mail: anyajobi@yahoo.com
}

Received: July 4, 2019

Accepted: July 19, 2019

Online Published: July 25, 2019

doi:10.5430/afr.v8n3p118

URL: https://doi.org/10.5430/afr.v8n3p118

\begin{abstract}
The study examined taxation and income inequality (GINI), specifically, it determined the impact of Value Added Tax (VAT), Custom and Excise Duties (CED), Petroleum Profit Tax (PPT) and Company Income Tax (CIT) on GINI in Nigeria from the year 1990 to 2016. The Cointegration and Error Correction Models (ECMs) were used to analyze the data. Augmented Dickey Fuller unit root was used to test for stationarity. Data were sourced from the Central Bank of Nigerian statistical bulletin, Federal Inland Revenue Service and the National Bureau of Statistics. The result revealed that VAT, CED and PPT had positive relationship with GINI when measured at $5 \%$ critical level, though VAT and CED were not significant. CIT had a negative but significant impact on GINI. Based on the findings, we conclude that only CIT was able to reduce income inequality. We therefore recommend that VAT should be imposed on goods and services consumed by high income earners. In respect of CED, government should address the level of tariffs; for PPT, there is need for adequate diversification of the economy; and for CIT, tax authority should harness corporate taxes to its fullness.
\end{abstract}

Keywords: income inequality (GINI), taxation, Error Correction Models (ECMs)

\section{Introduction}

Governments are responsible for providing some basic facilities for their citizens. This responsibility shouldered by the government of any country, mostly the least-developed countries, is immeasurable, and it mainly depends on the total revenue generated by such government (Ibadin \& Oladipupo, 2015). The essential role needed to be fulfilled by the government include economic stabilization, income redistribution, promoting fairness and equity, fiscal responsibility and accountability, provision of national goods and services as well as facilitating economic growth and development. Globally, one main source of revenue is taxation, and it is a means by which governments of various nations fulfill their obligations such as providing national goods and services, distribution of income and wealth, promoting growth and development.

Recent advocacies on policy reforms in most developing countries have often focused on improving social service delivery; designing market-friendly worldly institutions; establishing effective poverty-reduction programmes; trade and market liberalization (Ilaboya \& Ohonba, 2013). There is no gainsaying that this reform agenda holds some social and economical benefits. However, other fundamental areas that need reformations are revenue generation and income distribution. It is a fact that social and economic development would be encumbered by the scarcity of revenue resources and inefficient income distribution. Suffice it to say that the tax sub-sector is a veritable means of complementing total revenue generation and a tool to enhance income distribution. Action Aid (2013) found that a well-structured tax system could generate sufficient revenue to fund needed infrastructural development and to promote policy reforms. Organization for Economic Cooperation and Development (OECD) (2012) holds a similar view that the tax system has the potential to reduce income inequality. Emerging evidence found that addressing inequality of income can bring about improved sustainable economic growth over a longer period of time (Sameti \& Rafie, 2010; Ostry, Berg \&Tsangarides, 2014).

Inequitable distribution of income and its impact on poverty and human development is one of the most discussed economic issues in sub-Saharan Africa, especially in Nigeria (Awe \& Rufus, 2012; Action Aid, 2013; Tax Justice Network Africa (TJNA) and Christian Aid Report, 2014; Ogbeide \& Agu, 2015). Widening income inequality in Nigeria has brought on an argument based on the level to which taxes are to be used as a means of curbing inequality. Generally, taxes can cause inequality as well as reduce inequality (Office of National Statistics (ONS), 2011). Taxes in the least-developed countries have been found to be inefficient in addressing redistribution of income, politically 
demanding to execute, and potentially harmful to growth (Office of National Statistics(UK), 2011; Martinez-Vaquez, Volovi \& Liu, 2011; Ardanaz \& Scartascini, 2013; Bird \&Zolt, 2014; InternationalMonetary Fund, 2014).

In Nigeria, inequality is multifaceted and has manifested in the form of inadequate shelter, lack of access to other basic needs of life, like excellent water, health and decent food. In the view of Jibrin, Blessing, and Ifurueze (2012), oil accounts for about $90-95$ percent of the export revenue, 80 percent of the government's revenue in Nigeria and about 90 percent of foreign exchange earnings. Due to Nigeria's dependence on crude oil as posited by Martin and Crookes (2013), there are some indications of income inequality rising further with higher levels of oil production. The Nigerian government in a bid to reduce income inequality has introduced policies like Poverty Alleviation Programme (PAP), National Economic Empowerment and Development Programs (NEEDs) just to mention a few. Furthermore, taxation policies like pay as you earn (PAYE) and all forms of a progressive system of taxation such as income tax, have not yet achieved its main objective. The major contribution of tax policy as a redistributable instrument as stated by Chu, Davoodi, and Gupta (2000), should be to raise revenue needed to fund effective pro-poor and other vital government expenditure, and to avoid generating horizontal inequities, which referred to people who have the same ability to pay tax are charged differently.

The National Tax Policy of Nigeria (2012) states that in order to correct the imbalance in the direct tax system due to the over-reliance on revenue derived from the oil sector which is no longer seen as a sustainable source of revenue for the nation, there is a need to shift from direct taxation to indirect taxation. This is because indirect taxes are more efficiently realized providing a higher rate of returns and also stimulating economic growth in the sectors, whilst still meeting the revenue requirements. In the report of the Office of the National Statistics in the United Kingdom (UK) (ONS, 2011), the effects of taxes and benefits in United Kingdom on inequality over 30 years has shown that taxes overall made little difference to income inequality based on the fact that, though direct taxes reduce inequality but indirect taxes increase inequality by roughly the same amount. It is against this backdrop that this study is being undertaken. Meanwhile, there are few studies, which focused on taxation and income inequality in Nigeria (Awe \& Rufus, 2012; Bakare, 2012; Ilaboya \& Ohonba, 2013; Ogbeide \& Agu, 2015; Obaretin, Akhor \& Oseghale (2017). Most existing studies are from developed countries (Aasness, Benedictow, \& Hussien, 2002; Sameti \& Rafie, 2010; Iris, Martinez-Vazquez, \& Vulovic, 2012; Fu, 2016; ONS, 2016). However, four research questions, research objectives, and research hypotheses were formulated.

The following research questions have been raised to address the problem and to guide the study:

1. What is the effect Value-Added Tax on income inequality in Nigeria?

2. What is the impact of Customs and Excise Duties on income inequality in Nigeria?

3. What is the effect of Petroleum Profit Tax on income inequality in Nigeria?

4. What is the effect of Company Income Tax on income inequality in Nigeria?

The objectives of this study were to determine the impact of Value-added tax (VAT), custom and excise duties (CED), petroleum and profit tax (PPT) and company income tax (CIT) on income inequality in Nigeria. In line with the above, the research hypotheses were formulated in a null form to resolve the problem of the study: VAT, CED, CIT, and PPT do not have significant effect on income inequality.

The gap identified in the literature and business practices with respect to this study, is that, previous studies that examined the impact of direct and indirect taxes on income inequality did not rely exclusively on the features and characteristics of the tax composition.

The study thus significant in several ways. It is among the few studies to examine the impact of direct and indirect taxes on income inequality in Nigeria using more of tax composition to examine income inequality. The study also enhances knowledge and appreciates the growing importance of direct and indirect taxes as an effective and efficient tool for revenue generation as well as being used to achieve redistribution. The study outcome is relevant to the Federal Inland Revenue Service to acknowledge the fact that direct tax especially Company Income Tax should be strengthened to ensure more redistribution in Nigeria. This study will also provide a good reference source for researchers interested in the area of study especially to the academic community on similar issues.

The rest of the paper is structured thus: following the introduction is Section 2, literature review, which examined income inequality as well as empirical evidence on VAT, CED, CIT, PPT on income inequality in Nigeria. Section 3 is the methodology of the study with emphasis on research design, data and data source, and data analysis techniques. Section 4 is the estimation result and discussion of findings. Section 5 looked at the summary of findings, conclusion and recommendation. 


\section{Literature Review}

\subsection{Income Inequality}

Inequality is the state of not being equal especially in rights, opportunities and status (Oxford Advanced Learner's Dictionary). Inequality can be viewed from different perspectives. International Monetary Fund (IMF) (2014) divided economic inequality into four. First, is the inequality of outcome (interpersonal distribution of income). Second, is the inequality of wealth (distribution of wealth across individuals or households). Third, is the life-time inequality (distribution of incomes or earnings for an individual over his or her lifetime). Fourth, is the inequality of opportunity (the relationship between income inequality and social mobility i.e. the mobility between income groups across generations).The Development Strategy and Policy Analysis Unit (2015) state that economic inequality results into two views: inequality of outcomes and inequality of opportunities; Inequality of outcomes takes an ex-post or achievement-oriented perspective which refers to the material dimensions of well-being resulting to circumstances beyond one's control such as gender, ethnicity, family background, and so on. On the other hand, inequality of opportunities is an ex-ante or potential achievement perspectives focusing on the circumstances beyond one's control that affect one's potential outcomes.

OECD (2012) report states that income inequality measures fall into two categories: the Gini index known as one-number summary statistics and shares of income or percentile ratios also known as income distribution at various points. Lee, Kim and Cin (2013) noted that Gini- coefficient or index is a range on which Zero (0) is perfect equality and (1) is perfect inequality. According to Index mundi, Gini index (World Bank estimate) measures the extent to which the distribution of income among individuals or households within an economy deviates from perfectly equal distribution. The Gini is given by the area between the Lorenz curve and the $45^{\circ}$ line of equity from the origin. Bourguignon as cited in Omotola and Kabir (2015), states that a value of 0.55 and above is a high level of inequality, $0.45-0.55$ is middle-high, $0.35-0.45$ is middle and 0.35 and below is a low level of inequality.

Appergis (2015) posits that unequal distribution has been accredited to a variety of factors such as changes in skilled-based technology, globalization, liberalization of product and factor markets, and improved labour-force participation by low-skilled workers, raising share of high-income in couples and single parent households and the declining top marginal income tax rates of high earners. Igbuzor (2017) explores the drivers of inequality in Nigeria. He further stated that the main drivers of poverty and inequality are: retrogressive taxation, inadequate budgeting system and allocation, insufficient resource management and policy implementation, elite capture, cronyism and favouritism, and prohibitive cost of governance. Ilaboya and Ohonba (2013) opine that inequality of income can be reduced through a range of public policies such as good governance represented by transparency and accountability, public expenditure on health, housing and education, policies of more comprehensive growth pattern, and taxation.

\subsection{Tax System in Nigeria}

The Nigerian tax system comprises of the tax policy, tax administration and tax laws. This system works together to attain the nation's economic goal (Abiola \& Asiweh, 2012). In the report of Action Aid (2013), this tax system is multifaceted amid three-tiered fiscal authority at the federal, state and local governments; where all income received or revenue are shared and allocated to all levels. Ibadin and Oladipupo (2015) also stated that the tax system in a democratic nation is empowered by the bye-laws of Local Government authorities and the Acts passed by the National and State House of Assembly. In Nigeria, the Federal Inland Revenue Service (FIRS) administers taxes at the federal level while the State Internal Revenue Service (SIRS) administers taxes at the state. According to the National Tax Policy (2012) (NTP), taxation is the process by which taxes are collected within a given locality, and tax is a compulsory charge imposed by government on the profit or income of entities, persons, properties or transaction to yield revenue. The main objectives of the Nigeria Tax System are to promote fiscal accountability, growth and development, provide stable resources for the government in order to provide public goods and services, tackle income inequality, provide stabilized economy, promote equity and justice, and to address market imperfections (NTP, 2012). The Nigerian system of taxation is a means to address unequal distribution of income by charging the rich more and directing public expenditure to benefit poor. Action Aid Report (2013:20), posited that:

The Nigerian tax structure is seen by most citizens as a legal imposition, and often an undesirable imposition which bears no relation to the responsibilities of citizenship, or to the service provided by the state. Many Nigerian citizens provide electricity, water, education and other social amenities for themselves... It is therefore necessary to restore confidence to the citizens, by providing effective services and creating general awareness about taxation in the country. This will reduce the incidence of evasion, avoidance and non-compliance with relevant tax laws. 
Abugre, in Tax Justice Network Africa and Christian Aid Report (2014) opined that the unsuitably soaring level of poverty suffered by so many on the continent in sub-Saharan Africa is due to the absence of an effective and efficient tax system. Taxation according to the TJNA and Christian Aid Report (2014) provides a critical foundation for development, while tax is vital as it plays a key role in income and wealth redistribution and that a progressive tax policy is suitable for setting the public on a new track for creation and distribution of wealth. Taxation is not the only means used by government to address inequality of income; a wide variety of actions could be taken some of which are being funded through taxation, and they include: policies on the implementation of an appropriate minimum wage to enhance wages, promoting reform on land to mitigate the disparity of land ownership, and progressive public spending which seeks to raise the access, assets and income of the poor in the society. While these measures represent a strategy for equitable national development, the key objective of any strategy in curbing income inequality is redistributive taxation. Prasad (2008) opines that indirect taxes are more attractive than direct taxes as indirect taxes symbolize an easier way by which government revenue accrue. Martinez-Vazquez, Vulovic and Liu (2011) posited that the impact of taxation on inequality depends on the size of the system of taxation; since nations with a smaller tax system has a positive impact on inequality while nations with larger size tax system have a negative impact on income inequality. Empirical evidence on direct and indirect taxation on income inequality are discussed below:

\subsection{Value-Added Tax (VAT) and Income Inequality (GINI)}

Based on extant literatures on VAT AND GINI, Engel, Galetovic and Raddatz (1999) studied the distributional impact of the Chilean tax system and also assessed the sensitivity of redistribution of income to variations in structure of taxes and rates at the household level. They constructed a model incorporating the main allowances and taxes in place in Chile for 1996. However, major modifications of the tax structure such as raising the VAT from 18\% to $25 \%$ or substituting a $20 \%$ flat tax were considered for the present progressive income tax. They discovered that the system of taxation has little effects on redistribution. They also found the scope for direct redistribution through a progressive income tax is small, and they noted that after accounting for distribution of income, the slightly regressive but high-yield VAT decreased inequality of income compared to the strongly but low-yield progressive income tax.

Aasness, Benedictow and Hussien (2002) examined the distributional effect of twelve different taxes (direct and indirect) in Norway focusing on three collective measures: equality, average standard of living and Sen-welfare. The study showed that the distributional impact contrast strongly between the rankings and the tax reform. Meanwhile, the impact was determined by the change in the accumulative measure of standard of living, given a total number of individuals in a mini population divided by the change in total consumption. They further stated that a low VAT on food and electricity enhanced equality.

Sameti and Rafie (2010) analysed the interaction of redistribution of income, economic growth and taxes in Iran and some selected East Asian countries for the period 1990-2006. They used random effect estimation and panel data regression. They found the impact of goods and service tax (VAT) on income inequality and growth to be not significant.

Leathy, Lyons and Tol (2011) measured the distributional impacts of value-added tax (VAT) in Ireland based on the 2004 and 2005 Household Budget Survey to determine VAT payments by equivalent income of ten different household's composition and sizes. Micro-simulation model was used to ascertain the effect of VAT rate changes on a particular group of items and the related change in revenue. The general pattern of their results showed that the current system is highly regressive. This reflect that, the hardest hit was on the first households with ten persons, six person households, households containing a single adult with children and households in rural areas.

Iris, Martinez-Vazquez and Vulovic (2012) studied the government fiscal policies' impact on income inequality in Asia. Panel estimations for 150 countries between the periods of 1970 and 2009 were used. Their variables include: company tax; personal income tax; payroll taxes and social security contribution; taxes on goods and services including VAT and custom and excise duties. From their empirical results, they found the general taxes on goods and services, including VAT to be regressive in Asia. They therefore opined that a $1 \%$ rise in goods and service's tax in Asia increases inequality of income by $0.666 \%$ compared to $0.768 \%$ points in the rest of the world.

Okatch, Siddique and Rammohan (2013) investigated the determinants of income inequality in Botswana. They utilized the Ordinary Least Square (OLS) regression method to analyze factors increasing income inequality at the household level in Botswana. Explanatory variables such as primary and secondary education, number of working adults, age, number of children and value added tax were used. Their results showed that VAT contributes significantly to income inequality. They further suggested that VAT on goods and services highly consumed by 
low-income households, like food items, should be either zero rated or exempted while VAT should be imposed on goods heavily consumed by high-income households.

Alavuotunki and Pirttila (2015), examined the consequences of the Value-Added Tax on inequality using highquality macro data. They estimated the direct effect of VAT following the addition of first controls and VAT relations with middle and low-income nations. Their results revealed that VAT consequences had not been positive, contrasting previous results. They suggested that adoption of VAT has not led to increased inequality and has not undermined equitable development.

Erero (2015) analysed the effects in valued-added tax increment using a dynamic general equilibrium model of the national treasury in South Africa. The model comprises of a social accounting matrix (SAM) for the year 2010 and all important South African taxes. Five different simulations examined ranges from 1\% to 5\% VAT increase between the periods 2012 and 2018. The empirical result showed that an increase in VAT rate ensued by a marginal increase in GDP for the period between 2013 by $0.022 \%$ and 2018 by $0.115 \%$ respectively. The result also revealed a slight increase in the government revenue which could be used for distribution and alleviation of poverty. The researcher suggested that any policy measures aimed at stimulating growth, employment and redistribution of income can consider an increase in VAT rate as well as evaluating the trade-offs between a VAT and other taxes for future research.

Fu (2016) examined indirect tax increments on income gap between urban and rural areas in China using the analysis of Thayer Index from 1994 to 2013. The consumption expenditure data and the indirect tax burden for urban and rural inhabitants were determined. It was discovered that income gap existed between rural and urban areas in China following the process of economic and social developments. However, the main tax (indirect tax) of the country should be able to bridge the gap on income between these areas. Nonetheless, the study concluded that during the period of review, indirect taxes were found to be regressive between rural and urban residents. Specifically, VAT had a negative effect on income gap; consumption tax and business tax had a positive impact on income gap between these areas. He further opined that indirect tax, especially VAT is reducing income distribution as a whole.

Office of the National Statistics (ONS) (2016) report revealed that the measure of progressiveness based on the kakwani index indicates indirect taxes to have been progressive between 1977 and 2014/15 in the UK, although a number of fluctuations existed during this period. The overall pattern has been progressive. Indirect taxes such as VAT act to increase income inequality between 1978 by $1.5 \%$ point and 1991 by $3.5 \%$ point. Since then, there has been a very little change in the redistribution of indirect taxes.

\subsection{Custom and Excise Duties (CED) and Income Inequality (GINI)}

Empirical evidence regarding the effect of custom and excise duties is mixed. Cicowiez, Diaz-Bonilla and Diaz-Bonilla (2009) examined poverty, economic and inequality impact of both domestic and world trade reform in Argentina focusing on export taxes. They used a combination of models such as national CGE model, World Bank LINKAGE model, and micro simulations. From their review, they found full trade liberalization of world trade, including import taxes and subsidies but not export taxes for both agriculture and non-agricultural goods to reduce inequality and poverty in Argentina.

In the study of Iris, Martinez-Vazquez and Vulovic (2012), they found custom and excise duties to be regressive in Asia. Their results revealed an estimated impact of $0.174 \%$ for custom duties and $0.609 \%$ points for excises. Martinez-Vazquez, Vulovic and Moreno-Dodson (2012) carried out a research on the effect of tax and expenditure policy on the distribution of income between 1970 and 2009. They found that excise taxes, general consumption taxes, and custom duties had a negative effect on redistribution of income.

\subsection{Petroleum Profit Tax (PPT) and Income Inequality (GINI)}

Buccellato and Alessandrini (2009) in their empirical study, examined natural resources: a Blessing or a Curse, the role of inequality. They used an unbalanced panel of 122 countries over the period 1980-2004. Ores and metals were used to capture the effect of natural resources and inequality dynamics. Employing Regression analysis, their results revealed that ores and metals seemed to have a clear and significant role in enhancing inequality within countries, and that the economic dependence on export of ores and metals widens the gap between the two types of households.

In the study of Fum and Hodler (2009), they hypothesized using a Baseline regression, and found that natural resources raise income inequality in ethnically polarized societies, but reduce income inequality in ethnically homogeneous societies. The empirical findings supported their hypothesis. 
Moradi (2009) examined the effects of oil resource abundance on two major macroeconomic variables; economic growth and income distribution in Iran using data over the period 1968-2005. He employed the Error Correction Models, Co-integration test and the Autoregressive Distributed Lag (ARDL) bounds technique. The empirical results of both models confirm that although oil revenue has a positive effect on GDP and negative effect on Gini's coefficient. Though the magnitudes of the coefficients in both models were too small, the effect of oil revenue on economic growth and income distribution was not very strong.

Martin and Crookes (2013) used a mixture of quantitative and qualitative analysis. They determined oil shock vulnerabilities and impacts in Nigeria. They concluded on one hand that in terms of government spending and government's ability to subsidize the fuel price, higher oil prices have positive benefits, which had also benefited many Nigerians. On the other hand, increased oil prices were seen to have raised inequality leading to a shoot up in food prices, which negatively brings about poverty and inflation.

\subsection{Company Income Tax (CIT) and Income Inequality (GINI)}

In the report of Action Aid (2013), corporate tax symbolizes an increase share of taxes from a small number of taxpayers (the larger companies). It is significant for raising revenue due to the high revenue retrieved for a relatively small administrative effort. It was noted that large sum of money appeared to be lost by developing nations from companies, via tax evasion, exemptions, and avoidance. Nonetheless, company income taxes tend to be progressive. Interest in this area could be productive, in terms of reducing inequality and increasing revenue. Most extant literatures provide a mixed result on the effect of company income tax and income inequality.

Engel, et al. (1999), examined the correlation between taxes and income distribution in Chile. The study identified that a 15\% flat business tax (primera categoria) as one income tax in Chile has a neutral relationship with income distribution owing to the fact that income taxes levied on profits of company has no effect on income distribution.

Iris, Martinez-Vazquez and Vulovic (2012) study revealed that though the tax system tends to be progressive, the most efficient and effective tool for redistribution of income is public expenditure. In their study, company income $\operatorname{tax}$ (CIT) was found to reduced income inequality in other countries but was regressive in Asia owing to the fact that an increase in CIT by one percent will increase inequality by about 0.598 percent.

Martinez-Vazquez, Vulovic and Moreno-Dodson (2012) based on their research from 1970 to 2009 on the effect of expenditure and tax policy on income distribution found that faster growing nations with high a population growth rate tend to have high inequality. From their survey, they recognized that progressive taxes (corporate and personal) decreased inequality as it enhances income distribution. They further stated that the result of corporate taxes tends to be eroded away in an open or globalized economy and that 1 percent increase in the share of corporate tax to GDP reduces income inequality by 0.7 percent.

Ramot and Ichihashi (2012) investigated the effect of the structure of tax on economic growth and income inequality using a panel data set of 65 countries from 1970 to 2006 . They found corporate tax rate to be strongly negatively related to income distribution and economic growth. They also classified the nations into tax groups based on their average corporate tax rates and found high corporate tax rate above $40 \%$ corresponded with lower income inequality while corporate tax rate below $40 \%$ were found to be not significant to income inequality.

Ilaboya and Ohonba (2013) found that to redistribute wealth, company income taxes in Nigeria should be harnessed effectively. They also noted that all medium scale businesses should be listed and registered with the Corporate Affairs Commission for transparency and accountability purposes as this will improve the standpoint of a positive relationship and increase the tax ratio.

\subsection{Theoretical Framework}

The major theories underpinning this work are discussed below.

\subsubsection{Optimum Income Taxation Theory}

A major development from the standpoint of the optimal tax mix was the seminal paper of Atkinson and Stiglitz's in 1976. The Atkinson-Stiglitz theorem was the starting point in optimal tax literature. These researchers measured the relationship between indirect and direct taxes in the achievement of equity and efficiency objectives. This theory in the view of Slemrod (1990) is the study of designing and implementing a tax that reduces inefficiency and distortion in the market under given economic constraints through pareto optimal moves. According to the Atkinson and Stiglitz theory, a country where individuals vary simply in their income levels, government can charge a general tax on income but where the utility function is different between all commodities and labour, the appropriate tax design needed not to utilize indirect taxation. Mirrlees (1971) explored the theory of optimum taxation in 1971; he 
discovered that an approximately income tax schedule with an administrative advantage is desired and that the income tax-mix is less useful means for decreasing inequalities. He further postulated that a complementary tax design should be devised to avoid the difficulties faced with income-tax. According to Martinez-Vazque, Vulovic and Liu (2011), the option of the direct-indirect tax mix is also expected to have significant effect in other areas of the economy, including variation in redistribution of income, macroeconomic stability and flows from foreign direct investment. This shows that an optimal tax-mix design should be a combination of an efficient and effective direct and indirect tax in any economy.

\subsubsection{Ability to pay Theory}

This theory flows from the optimal tax theory; it was propounded by Arthur Cecil Pigou (1877- 1959). It examines tax liability from the perspective of a compulsory levy imposed by the state without quid pro quo benefits. This theory is also termed equality of sacrifice theory or faculty theory and it states that an individual must pay tax and that his relative share of tax burden is determined in relation to the capacity of the citizen (Bhartia, 2009). This shows that taxes paid by a citizen, and his comparative share in the total tax burden are determined in accordance to his or her capacity to pay. This, therefore, indicates that high-income earners should pay more than low-income earners. This theory is supported by both socialist and non-socialist thinkers because it is consistent with the concepts of equity and justice as it became part of the theory of welfare economics (Chigbu, Akujuobi \&Appah, 2012). According to Wikipedia, equity is first determined by assessing an individual ability to pay. The sub-set of the ability to pay theory are the horizontal and vertical equity. Horizontal equity suggests that if people who have equal ability to pay should actually pay the same amount in taxes while vertical equity states that government should implement higher taxes on those who have stronger abilities to pay than those who have lower ability to pay.

\subsubsection{Expediency Theory}

This theory according to Ibadin and Oladipupo (2015) is rooted in the principle of economies, and it explains the efficiency, effect and economies of the instrument of taxation. Ogbonna and Appah (2012) noted that every tax proposed must pass the assessment of practicality, and this test must be considered by the authorities in deciding a tax policy. The theory is based on a link between the state activities and the tax liability because it validates the imposing of taxes for providing a basis for distributing tax burden between the members of the society and also for financing state activities (Bhartia, 2004; Musgrave \& Musgrave, 2004).

This theory best explains the study in that taxation is a system that provides an effective and efficient set of policy instruments to governments. These policies are designed strategically, to remedy fiscal and social evils in the nation such as unemployment, corruption, regional disparities and income inequalities. This theory is adopted for this study because it captures all taxes and inequality.

\section{Methodology}

The research design used for this is an ex-post facto design. This method was adopted because of the pre-manifestation of the use of this data in literature. The study is country-specific. To this end, the population of this study is direct and indirect taxes and income inequality in Nigeria while the sample includes direct taxes represented by company income tax (CIT) and petroleum profit tax (PPT); and indirect taxes represented by value added tax (VAT) and customs and excise duties (CED) from 1990 -2016.

Secondary sources of data were used in this study. Time series data spanning a period of 27years, ranging from 1990-2016 was obtained from Central Bank of Nigeria (CBN) Statistical Bulletin, Index Mundi, National Bureau of Statistics and Federal Inland Revenue Service of Nigeria. However, Gini's coefficient of Nigeria was from 1990-2016. Due to the non-availability of data on value-added tax (VAT) before 1993, VAT was from 1994 to 2016. Meanwhile, petroleum profit tax, customs and excise duties and company income tax were from 1990-2016.

\subsection{Data Estimation Techniques and Model Specification}

\subsubsection{Data Estimation Techniques}

Data analysis was conducted using a combination of Error Correction Models (ECMs) and co-integration to test for the stationarity of time series data. The ECMs was used because of its ability to induce flexibility by combining short-run dynamic and long-run equilibrium at the same time (Iyoha, 2004). The Augumented Dickey Fuller (ADF) unit root test was used to test for Stationarity of the variables. The ADF test is superior to Dickey fuller test because it is adjusted for serial correlation. It is the most accepted method of testing for unit roots test often related to time-series data analysis 


\subsubsection{Model Specification}

The model of the study was an adaptation and modification of the models of Ilaboya and Ohonba (2013) and Martinez-Vazquez et al. (2012). The models stated below were modified to suit the country-specific nature, the peculiarity of this study, and to ascertain the effect of taxation (indirect and direct) on income inequality in Nigeria.

Ilaboya and Ohonba (2013) studied direct versus indirect tax and income inequality in Nigeria. They used multivariate economic analysis based on macroeconomic variables and tax data between 1980 and 2011 for Nigeria. The macroeconomic variables used were Gross Domestic Product per capita, private sector credit to Gross Domestic Product ratio and labour-force participation while the tax data includes tax ratio, total tax revenue and tax burden. Their model was stated thus:

$$
\text { GiniCo }=\beta_{1} \text { taxratio }_{\mathrm{t}}+\beta_{2} \mathrm{TTR}_{\mathrm{t}}+\beta_{3} \text { taxratio } * \mathrm{TTR}_{\mathrm{t}}+\beta_{4} \mathrm{TBUD}_{\mathrm{t}}+\beta_{5} \mathrm{GDPPC}_{\mathrm{t}}+\beta_{6} \text { Pcredit }_{\mathrm{GDP}_{\mathrm{t}}}+\beta_{7} \mathrm{LFP}_{\mathrm{t}}+\varepsilon_{\mathrm{t}}
$$

\section{Where:}

GiniCo $=$ Gini Coefficient from 1980-2011

Tax ratio $=$ TotalDirectTax $/$ TotalIndirectTax

TTR $=$ Total tax revenue

Tax ratio $*$ TTR $=($ TotalDirectTax/TotalIndirectTax $) *$ Total tax revenue

TBUD $=$ Tax Burden $=$ TotalTaxRevenue/GDP

GDPPC $=$ GDP per capita

Pcredit/GDP $=$ Private sector credit to GDP ratio

LFP $=$ Labour force participation

$\varepsilon=$ Error term and $\beta_{1}$ to $\beta_{7}<0$ unknown coefficients of the variables.

Martinez-Vazquez et al. (2012) examined the impact of taxes and expenditure polices on income distribution from 1970 to 2009, where they used fiscal variables of both tax and public expenditure instrument such as personal income tax, company income tax, general sales tax, payroll taxes and custom and excise using the model:

$$
\operatorname{Gini}_{\mathrm{it}}=\alpha \operatorname{gini}_{\mathrm{it}-1}+\mathrm{yf}_{\mathrm{it}} \beta \mathrm{x}_{\mathrm{it}}+\mathrm{vi}+\varepsilon_{\mathrm{it},} \mathrm{i}=1, \ldots, \mathrm{n}, \mathrm{t}=1, \ldots, \mathrm{T}
$$

Where:

Gini $_{\text {it }}=$ Gini coefficient in country $I$ in year $t, i=1, \ldots n, t=1, \ldots T$

$\alpha$ gini $_{\mathrm{it}-1}=$ Value in year $\mathrm{t}-1$.

$\mathrm{f}_{\mathrm{it}}=$ Vector of fiscal variables of both tax and public expenditure instruments in country $\mathrm{I}$ in year $\mathrm{t}$, the variables are Personal income tax, Company income tax, general sales tax, SSC and payroll taxes, excise and custom duties.

$\mathrm{x}_{\mathrm{it}}=$ Set of control variables.

$\mathrm{vi}=$ unobserved country fixed effects.

Flowing from these models, the model for this study which comprises of tax composition and income inequality is stated below:

$$
\mathrm{GINI}_{\mathrm{t}}=\beta_{0}+\beta_{1} \mathrm{VAT}_{\mathrm{t}}+\beta_{2} \mathrm{CED}_{\mathrm{t}}+\beta_{3} \mathrm{PPT}_{\mathrm{t}}+\beta_{4} \mathrm{CIT}_{\mathrm{t}}+\varepsilon_{\mathrm{t}}
$$

Where:

$\mathrm{GINI}_{\mathrm{t}}=$ Gini coefficient represents the dependent variable;

$\mathrm{VAT}_{\mathrm{t}}=$ Value Added Tax;

$\mathrm{CED}_{\mathrm{t}}=$ Custom and Excise Duties;

$\mathrm{PPT}_{\mathrm{t}}=$ Petroleum Profit Tax;

$\mathrm{CIT}_{\mathrm{t}}=$ Company income tax;

$\varepsilon=$ Error term;

$\beta_{0}=$ Intercept of the relationship; and

$\beta_{1}-\beta_{4}<0$ Unknown coefficients of the variables, this connotes that the independent variables are expected to have a negative relationship with income inequality particularly in consonance with existing theory. Independent variables 
represented by the tax instruments are value-added tax, petroleum profit tax, custom and excise duties and company income tax.

\section{Data Presentation and Analysis of Results}

\subsection{Test for Stationarity}

Table 1. Augmented Dickey Fuller Unit Root Test

\begin{tabular}{cccccccccc}
\multicolumn{7}{c}{ @LEVELS } & @ 2 ${ }^{\mathrm{ND}}$ DIFFERENCE \\
\hline VARIABLES & ADF & $\begin{array}{c}\text { CRITICAL } \\
\text { VALUE }\end{array}$ & Prob & REMARK & VARIABLE & ADF & CRITICAL & Prob & REMARK \\
\hline GINI & -2.6186 & -2.9810 & 0.1021 & Non-stationary & D(GINI,2) & -6.2513 & -2.9980 & 0.0000 & stationary \\
CIT & 3.7793 & -3.0206 & 1.0000 & Non-stationary & DCIT,2) & -16.250 & -2.9980 & 0.0000 & Stationary \\
PPT & 1.8847 & -3.0206 & 0.9995 & Non-stationary & D(PPT,2) & -5.9588 & -2.9918 & 0.0000 & Stationary \\
VAT & -1.9081 & -3.0048 & 0.3227 & Non-stationary & D(VAT,2) & -7.5412 & -3.0207 & 0.0000 & Stationary \\
CED & -1.1767 & -2.9862 & 0.6679 & Non-stationary & D(CED,2) & -6.6574 & -2.9980 & 0.0000 & Stationary
\end{tabular}

\section{Source: Researchers Compilation (2018)}

From Table 1, above gives an indication of the stationarity test conducted using the Augmented Dickey-Fuller test. From the table above it was observed that all the variables were found to be non-stationary at levels but became stationary at second difference. Therefore, indicating the existence of a long run relationship among the estimating parameters. Furthermore the error term (ECM) was found to be stationary at level which also gave a clear indication of the need to take into account of the long run relationship that exists among the variables.

\subsection{Tests for Cointegration}

Table 2.

\begin{tabular}{ccccc}
\hline Dependent & tau-statistic & Prob. ${ }^{*}$ & z-statistic & Prob. ${ }^{*}$ \\
\hline DGINI & -5.770329 & 0.0207 & -74.21421 & 0.0000 \\
DCIT & -2.726949 & 0.7499 & 8.841027 & 1.0000 \\
DCED & -2.999411 & 0.6337 & -12.69068 & 0.6413 \\
DPPT & -2.212961 & 0.9041 & 12.31984 & 1.0000 \\
DVAT & -3.558106 & 0.4002 & -28.67503 & 0.0011 \\
\hline
\end{tabular}

\section{Source: Researchers compilation (2018)}

From Table 2 above, the cointegration test conducted revealed that there is the existence of a cointegrating equation in the model judging by the tau-statistics and Z-statistics that revealed probability values that are less than the critical $5 \%$ value. 


\subsection{Regression Result (Error Correction Models)}

Table 3.

Dependent Variable: D(GINI)

Method: Least Squares

Date: 02/25/18 Time: 17:03

Sample (adjusted): 19952016

Included observations: 22 after adjustments

HAC standard errors \& covariance (Bartlett kernel, Newey-West fixed

bandwidth $=3.0000$ )

\begin{tabular}{ccccc}
\hline Variable & Coefficient & Std. Error & t-Statistic & Prob. \\
\hline D(CIT) & $-1.56-08$ & $5.59-09$ & -2.788492 & 0.0131 \\
D(CED) & $9.19-08$ & $1.87-07$ & 0.492131 & 0.6293 \\
D(PPT) & $6.27-09$ & $1.35-09$ & 4.649113 & 0.0003 \\
D(VAT) & $2.13-08$ & $2.61-08$ & 0.818255 & 0.4252 \\
ECM(-1) & -0.916742 & 0.138696 & -6.609735 & 0.0000 \\
C & -0.001771 & 0.008005 & -0.221254 & 0.8277 \\
R-squared & 0.508217 & Mean dependent var & 0.003636 \\
Adjusted R-squared & 0.354535 & S.D. dependent var & 0.050289 \\
S.E. of regression & 0.040403 & Akaike info criterion & -3.352837 \\
Sum squared resid & 0.026118 & Schwarz criterion & -3.055280 \\
Log likelihood & 42.88120 & Hannan-Quinn criter. & -3.282741 \\
F-statistic & 3.306940 & Durbin-Watson stat & 2.002926 \\
Prob(F-statistic) & 0.030632 & Wald F-statistic & 10.79974 \\
Prob(Wald F-statistic) & 0.000112 & . & \\
\hline
\end{tabular}

\section{Source: Eviews 8.0}

From Table 3, the regression result conducted on the variables in the model, it was observed that Company income tax was found to have a negative impact on the Gini coefficient which is a measure for inequality. It was also found to be statistically significant when measured at 5\% critical level. Custom and excise duties was found to have a positive effect on Gini coefficient therefore indicating that on the average the income generated from custom and excise duty brings an increase in income inequality in Nigeria as a country. Petroleum profit tax was found to impact positively on income inequality in Nigeria. It was also found to be statistically significant at $5 \%$ critical level. Value added tax was found to have a positive effect on income inequality in Nigeria. It was also found not to be statistically significant when measured at 5\% critical level. The error term which is depicted as ECMs was found to have a value of -0.9 with an associate probability of 0.00 therefore indicating that the model has the capability of leaving its state of disequilibrium to equilibrium at a speed of $91 \%$ annually.

Furthermore, with respect to the summary statistics, the coefficient of determination depicted as $\mathrm{R}^{2}$ stood at a value of 0.50 therefore indicating that on the average the model accounted for $50 \%$ of the systematic variation, while the remaining 50\% left unaccounted for and is captured by the stochastic error term. The F-statistics which measures the overall significance of the variables stood at a value of 3.3 with an associate probability value of 0.03 therefore indicating that the variables are jointly statistically significant when tested at 5\% critical level. The Durbin Watson statistics which account for the presence of autocorrelation in the model stood at a value of 2.0 therefore indicating the absence of first order serial correlation. 


\subsubsection{Test of Hypotheses}

Under this section, each hypothesis was tested individually in relation to the level of significance, they are presented in a null form below:

Test of Hypothesis 1

$\mathrm{H}_{0}$ : Value-Added Tax (VAT) has no significant effect on income inequality in Nigeria.

Decision Rule and Decision:

Accept $\mathrm{H}_{0}$ if the P-Value is greater than 0.05 and reject Ho if otherwise. Since the p-value 0.425 (Table 1) is greater than the level of significance 0.05 , we therefore accept the null hypothesis that value added tax has no significant effect on income inequality in Nigeria at 0.05 significance level.

Test of Hypothesis 2

$\mathrm{H}_{0}$ : Custom and excise duty (CED) has no significant impact on income inequality in Nigeria.

Decision Rule and Decision:

Accept $\mathrm{H}_{0}$ if the P-Value is greater than 0.05 and reject Ho if otherwise. Since the p-value 0.629 (Table 1) is greater than the level of significance 0.05 , we therefore accept the null hypothesis that custom and excise duties has no significant impact on income inequality in Nigeria at 0.05 level of significance.

Test of Hypothesis 3

$\mathrm{H}_{0}$ : Petroleum profit tax (PPT) has no significant effect on income inequality in Nigeria.

Decision Rule and Decision:

Accept $\mathrm{H}_{0}$ if the $\mathrm{P}$-Value is greater than 0.05 and reject Ho if otherwise. Accept Ho if the P-Value is greater than 0.05 and reject Ho if otherwise. Since the p-value 0.003 is less than the level of significance 0.05 (Table 1) we reject the null hypothesis that petroleum profit tax has no significant effect on income inequality in Nigeria at 0.05 significant level.

Test of Hypothesis 4

$\mathrm{H}_{0}$ : Company income tax (CIT) has no significant impact on income inequality in Nigeria.

Decision Rule and Decision:

Accept $\mathrm{H}_{0}$ if the $\mathrm{P}$-Value is greater than 0.05 and reject Ho if otherwise. Since the p-value 0.013 is less than the level of significance 0.05 (Table 1) we reject the null hypothesis that company income tax has no significant impact on income inequality in Nigeria at 0.05 significant level.

\subsection{Diagnostic Analysis}

Table 4.

\begin{tabular}{cccc}
\hline \multicolumn{4}{c}{ Breusch-Godfrey Serial Correlation LM Test: } \\
\hline F-statistic & 1.322248 & Prob. F(2,14) & 0.2979 \\
Obs*R-squared & 3.495385 & Prob. Chi-Square(2) & 0.1742 \\
\hline
\end{tabular}

Source: Eviews8.0

From Table 4 above, test for serial correlation in the model was carried out using Breusch-Godfrey Lagrange Multiplier (LM) test at $5 \%$ significance and the result showed that there is no problem of first order serial correlation in the model. 
Table 5 .

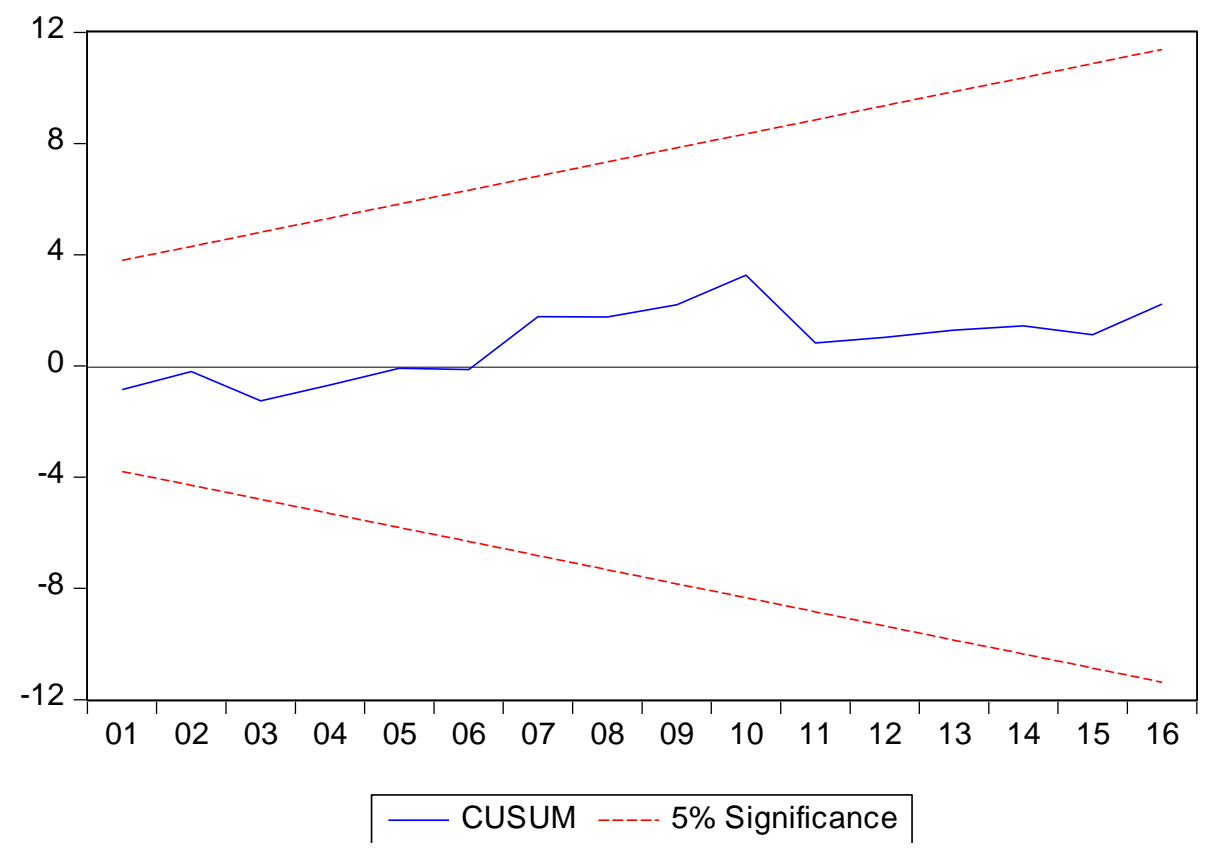

The CUSUM test in Table 5 above was used to test for stability, based on the result, the lines for the cumulative sum lies within the $5 \%$ critical lines and hence this suggests that parameters of the model are stable.

Table 6.

\begin{tabular}{cccc}
\hline & Value & Df & Probability \\
\hline t-statistic & 1.140268 & 15 & 0.2721 \\
F-statistic & 1.300211 & $(1,15)$ & 0.2721 \\
Likelihood ratio & 1.745685 & 1 & 0.1864
\end{tabular}

In Table 6, the Ramsey RESET test for misspecification error of the model revealed that the model was not mis-specified with high p-values that were greater than 0.05 .

Table 7.

\begin{tabular}{cccc}
\hline Variable & $\begin{array}{c}\text { Coefficient } \\
\text { Variance }\end{array}$ & $\begin{array}{c}\text { Uncentered } \\
\text { VIF }\end{array}$ & $\begin{array}{c}\text { Centered } \\
\text { VIF }\end{array}$ \\
\hline DCIT & $9.19-16$ & 3.640109 & 3.435843 \\
DCED & $3.14-13$ & 1.607586 & 1.022166 \\
DPPT & $2.64-17$ & 3.817796 & 3.449278 \\
DVAT & $7.49-15$ & 1.028842 & 1.028786 \\
C & 0.000397 & 1.748652 & NA
\end{tabular}

From Table 7, the Variance Inflator Factor revealed that there is no issue of multicollinearity in the model. 
Table 8 .

\begin{tabular}{cccc}
\hline \multicolumn{4}{c}{ Heteroskedasticity Test: Breusch-Pagan-Godfrey } \\
\hline F-statistic & 0.202879 & Prob. F(5,16) & 0.9565 \\
Obs*R-squared & 1.311634 & Prob. Chi-Square(5) & 0.9337 \\
Scaled explained SS & 1.058615 & Prob. Chi-Square(5) & 0.9577 \\
\hline
\end{tabular}

Source: Eviews8.0

From Table 8, the Breuch-Pagan-Godfrey test for heteroskedasticity revealed the presence of homoskedasticity.

\subsection{Discussion of Findings}

Value-added tax (VAT) was found to have a positive relationship with income inequality (GINI) in Nigeria. It was also found to be statistically not significant when measured at 5\% critical level. This means that VAT increased income inequality. However, the study is in line with findings of Sameti and Rafie (2010), who found non significant relationship between VAT and GINI in Iran and some selected Eastern Asian Countries. Furthermore, Leathy et al. (2011), study revealed a highly positive effect of VAT on income inequality in Ireland. Iris et al. (2012) also found VAT to increase income inequality in Asia. ONS (2016), result showed VAT to increase GINI in UK in 1991 by 3.5\% point. Meanwhile, this finding conflict with the research work of Engel et al. (1999), who found the slightly regressive but high-yield VAT to reduce GINI in Chile. Aasness et al. (2002) also found VAT on food and electricity to enhance equality in Norway. Alavuotunki and Pirttila (2015), revealed a negative effect of VAT on GINI; Erero (2015) results showed that a slight increase in VAT rate would increase revenue and distribute income in South Africa. Fu (2016), found that VAT had a negative effect on income Gap, thereby reducing income inequality in China.

Custom and excise duty (CED) was found to have a positive relationship with Gini's coefficient (GINI), this implies that it increased income inequality in Nigeria. This finding is in line with the findings of Iris et al. (2012) who found CED to have a positive impact of $0.174 \%$ and $0.609 \%$ respectively on GINI in Asia. The study is at variants with the findings of Cicowiez et al. (2009) who found the import but not export taxes and subsidies to have a negative effect on GINI in Argentina. Meanwhile, Martinez-Vazquez et al. (2012), found CED to have a negative effect on income inequality.

Petroleum profit tax (PPT) was found to have impacted positively on income inequality (GINI) in Nigeria. This study is in tandem with the findings of Martin and Crookes (2013) who found higher oil prices to increase income inequality in Nigeria leading to high rate of poverty and inflation but at variants with the findings of Moradi (2009) who found the effect of oil resource abundance in Iran to have a negative effect on GINI.

Company income tax was found to have a negative impact on the Gini coefficient which is a measure for inequality. It was also found to be statistically significant when measured at $5 \%$ critical level. This finding is in line with the study of Piketty and Qain (2009), who opined that corporate taxes are generally viewed to be progressive hence decrease income inequality. Martinez-Vazquez et al. (2012) also found 1\% increase in corporate tax to reduce income inequality by $0.7 \%$. Even so, Ramot and Ichihashi (2012) revealed company income tax to have a negative effect on income inequality. Ilaboya and Ohonba (2013) study, discovered that CIT in Nigeria should be harnessed to improve the positive position of the taxes in order to increase the tax ratio. Nonetheless, this finding is at variants with the findings of Iris, et al. (2012), who found CIT to be regressive in Asia owing to the fact that a $1 \%$ increase in CIT will increase inequality of income by $0.598 \%$.

The study is limited in that it determined the effect of both direct and indirect taxes but not all tax compositions were represented, for example, the personal income tax (PIT) which was not included due to unavailability of data in Nigeria. The study is country-specific with focus on Nigeria, and these findings may not be applicable to other countries. In the area of data collection, the study focused on the year 1990 to 2016, but 2017 and 2018 were not included in this study due to inability to get data for these years as at the time the study was carried out.

\section{Summary of Findings, Conclusion and Recommendation}

The findings of the study were as follows: Value-added tax (VAT) was found to have a positive effect when measured at 5\% critical level on income inequality (GINI) in Nigeria. It was, however, not statistically significant; Custom and 
excise duty (CED) was found to have a positive impact on income inequality (GINI) in Nigeria. It was, however, not statistically significant; Petroleum profit tax (PPT) was found to have a positive and statistically significant effect on income inequality (GINI) in Nigeria; and Company income tax (CIT) was found to have a negative and statistically significant effect when measured at $5 \%$ critical level on income inequality in Nigeria.

From the above findings, the study's concludes that all tax variables used exerted both statistically significant and not significant impact on income inequality when measured at 5\% level of significance. However, only CIT was found to decrease income inequality while VAT, PPT and CED increased income inequality in Nigeria. In general, the study conclusion reveals that direct taxes reduce income inequality than indirect taxes.

This study makes the following recommendations. VAT was found to have a positive relationship with income inequality in Nigeria. It is therefore recommended that VAT on goods and services heavily consumed by lowincome households, like food items, should be either reduce or totally exempted, while VAT should be imposed on goods heavily consumed by high-income households. CED was found to have a positive relationship with income inequality in Nigeria. It is therefore recommended that government should address the tariffs placed on exportation of some goods and services to reduce the level of income inequality that is prevalent in the society. PPT was found to impact positively on income inequality in Nigeria. It is therefore recommended that government should seek for adequate diversification of the economy to reduce the over dependence on crude products. CIT was found to have a negative impact on the Gini coefficient which is a measure for inequality. From the findings, it can therefore be seen that corporate taxes have a role to play in reducing the level of income inequality in the society. It is therefore recommended that government as well as tax authority should create an adequate avenues in which this corporate tax will be harnessed to the fullest to avoid any form of evasion by tax offenders.

The study makes recommendations for further studies to include all taxes, especially personal income tax, capital gains tax, etc. to thoroughly evaluate the distributional impact of taxation and income inequality in Nigeria. And relative studies should be carried out, comparing the effect taxation and income inequality in Nigeria and other countries.

The study contributed to knowledge as follows: it compliments studies in the area of taxation and income redistribution as compared to most studies, which had used cross country data and also specific studies, which had used aggregated and macroeconomics data, while this study made use of micro simulation data.

The emphasis of this study was on the distributional impact of the decomposition of taxes, which are direct taxes represented by company income tax (CIT) and petroleum profit tax (PPT); and indirect taxes represented by valueadded tax (VAT) and custom and excise duty (CED).

\section{References}

Aasness, J., Benedictow, A. \& Hussien. (2002). Distributional efficiency of direct and indirect taxes. Economic Research Programme on Taxation, 69, 1-27.

Abiola, J. \& Asiweh, M. (2012). Impact of tax administration on government revenue in a developing economy-a case study of Nigeria. International Journal of Business and Social Science, 3(8), 99-113.

Action Aid. (2013, July). Tax justice: The domestic perspective. Retrieved from http:// www.actionaid.org.uk.

Alavuotunki, K. \& Pirttila, J. (2015). The consequences of the Value-added tax on inequality. United Nations University World Institute for Development Economic Research, 1-38.

Appergis, N. (2015). Does renewable production affect income inequality? Evidence from an international panel of countries. Applied Economics Letters, 2(3), 23-44. https://doi.org/10.1080/13504851.2014.982852

Atkinson, A. B. \& Stiglitz, J. E. (1976). The design of tax structure: direct and indirect taxation. Journal of Public Economics, 6(1976), 55-75. https://doi.org/10.1016/0047-2727(76)90041-4

Awe, A. S. \& Rufus, O. O. (2012). Determinant of income distribution in the Nigeria Economy:1977-2005. International Business and Management, 5(1),126-137.

Bakare, A. S. (2012). Measuring the income inequality in Nigeria: the Lorenz curve and Gini-coefficient Approach. American Journal of Economics, 2(1), 47-52. https://doi.org/10.5923/j.economics.20120201.06

Bird, R. M. \& Zolt, E. M. (2014). Redistribution via taxation: The Limiting Role of the Personal Income tax in Developing countries. Journal of Economics and Finance, 15(2), 625-683.

Buccellato, T. \& Alessandrini, M. (2009). Natural resources: a Blessing or a Curse? The role of inequality. Centre for Financial and Management Studies. Discussion Paper 98. 
Central Bank of Nigeria Annual Statistical Bulletin. (2017). Retrieved from http://www. Cbn.gov.ng >statbulletin/net.

Chigbu, E. E., Akujuobi, L. E. \& Appah, E. (2012). An empirical study on the causality between economic growth and taxation in Nigeria. Current Research Journal of Economic Theory, 4(2), 29-38.

Chu, K., Davoodi, H. \& Gupta, S. (2000). Income distribution and tax and government social spending policies in developing countries. International Monetary Fund Working Paper, WP/00/62, 1-41. https://doi.org/10.5089/9781451848281.001

Cicoweiz, M., Diaz-Bonilla, C. \& Diaz-Bonilla, E. (2009). Impacts of trade liberalization on poverty and inequality in Argentina. Agricultural Distortions, Working Paper Series 52793. https://doi.org/10.1596/28170

Development Strategy and Policy Analysis Division (2015). Concepts of inequality. Development Policy and Analysis Division Department of Economic and Social Affairs, Development issues 1.

Engel, E.M.R.A., Galetovic, A. \& Raddatz, C.E. (1999). Taxes and income distribution in Chile: Some unpleasant redistributive arithmetic. Journal of Development Economics, 59(1),155-192.

Erero, J. L. (2015). Effects of increases in value-added tax: A Dynamic CGE Approach. Economic Research Southern Africa, 558.

Fu, R. (2016) Does Indirect Tax Increase the Income Gap between Urban and Rural Areas? Open Journal of Social Sciences, 4, 170-176. http://dx.doi.org/10.4236/jss.2016.41021

Fum, R. M. \& Hodler, R. (2009). Natural resources \& income inequality: The role of ethnic divisions. Oxford Centre for the Analysis of Research Rich Economies, OxCarre Research Paper 23.

Ibadin, P. O. \& Oladipupo, A. O. (2015), indirect taxes and economic growth in Nigeria. EKON.MISAO I PRAKSA BDK.GOD, 24(2), 345-364.

Ilaboya, O. J. \& Ohonba, N. (2013). Direct versus indirect taxation and income inequality. European Journal of Accounting Auditing and Finance Research, 1(1), 1-15.

Igbuzor, O. (2017). Opinion review on income inequality in Nigeria: Exploring the drivers. Retrieved from http:// www.THEWILLNigeria.com/news/ net.

IMF (2014). Fiscal policy and income inequality. IMF working paper.

Iris, C., Martinez-Vazquez, J. \& Vulovic, N. (2012). Government fiscal policy and Redistribution in Asian Countries. Asian Development Bank, Working paper series, 1-55.

Index Mundi. (2017). Retrieved from http:// www.indexmundi.com

Iyoha, M. A. (2004). Applied econometrics (2 Ed.). Benin City: Mindex Publishing.

Klazar, S. \& Slintakova, B. (2010). The impact of harmonization on distribution of VAT in the Czech Republic. Prague Economic Papers, 2(2), 133-149. https://doi.org/10.18267/j.pep.368

Leathy, E. Lyons, S. \& Tol, R. S. (2011). The distributional effects of value added tax in Ireland. The Economic and Social Review, 42(2), 213-235.

Lee, H., Kim, J. \& Cin, B.C. (2013). Analysis on the determinants of income inequality in Korea. International Journal of Advanced Science and Technology, 53, 96-110.

Martinez-Vazquez, J., Vulovic, V. \& Liu, Y. (2011). Direct versus indirect taxation: Trends, theory and economic significance. The Elgar Guide to Tax Systems, Edward Elgar Publishing. 37-92 https://doi.org/10.4337/9780857933898.00009

Martinez-Vazquez, J., Vulovic, V. \& Moreno-Dodson, B. (2012). The impact of tax and expenditure policies on income distribution: Evidence from large panel of countries. https://doi.org/10.2139/ssrn.2188608

Martin, W. \& Crookes, D. (2013, June 30). Oil shock vulnerabilities \& impacts: Nigeria case study. Report submitted to UK Department for International Development,

Mayah, E. (2017, May). Income inequality in Nigeria: Exploring the drivers. Retrieved from http://www.oxfamdocument.Com/2017/05/income-inequality-in-nigeria.

Moradi, M. A. (2009). Oil resource abundance, economic growth and income distribution in Iran. Research Gate.

National Bureau of Statistics. (2017). Retrieved from http://www.nigerianstat.gov.ng/net.

National Tax Policy of Nigeria. (2012). Final Draft from the Ministry of Finance. 
Obaretin, O., Akhor, S. O. \& Oseghale, O.E. (2017). Taxation an effective tool for income redistribution in Nigeria. Mediterranean Journal of Social Sciences, 8(4), 187-196. https://doi.org/10.1515/mjss-2017-0017

Ochei, O.O. (2010, July 12). Nigerian tax reform: Challenges \& prospects. Retrieved from: http://www.org/others/nigeria-tax reforms.

OECD (2012). Income inequality and growth: the roles of taxes and transfers. OECD Economics Department, Policy Notes, 9, 1-12.

OECD (2015). In it together: Why less inequality benefits all. Retrived from http://www.oecd.org/net.

Ogbeide, E. N. O. \& Agu, D. O. (2015). Poverty and income inequality in Nigeria: any causality? Asian Economic and Financial Review, 5(3), 439-452 https://doi.org/10.18488/journal.aefr/2015.5.3/102.3.439.452

Okatch, Z., Siddique, A. \& Rammohan, A. (2013). Determinants of income inequality of Botswana. University of Western Austrialia Business School, 13(15), 1-41.

Office of National Statistic, UK (2011, September). Taxes makes little difference to income inequality. Retrieved from http://www.statistics.gov.uk/StatBase/Product.asp?vlnk=10336.

Office of National Statistic, UK (2016, September 23).The effects of taxes and benefits on income inequality: 1977 to financial year ending $2015 \mathrm{http}: / / w w w . s t a t i s t i c s . g o v . u k / S t a t B a s e / P r o d u c t . a s p ? v l n k=10336$.

Omotola, A. M. \& Kabir, K. S. (2015). Assessing income inequality in North-Eastern Nigeria. Journal of Poverty, investment and Development, 16(1), 33-39.

Ostry, J., Berg, A. \& Tsangarides, C. (2014). Redistribution, Inequality, and Growth, IMF Staff Discussion Note. Washington https://doi.org/10.5089/9781484352076.006

Oxford Advanced Leaner's Dictionary $8{ }^{\text {th }}$ Ed. Oxford University Press. Oxford, United Kingdom.

Pikkety, T. \& Qian, N. (2009). Income inequality and progressive income taxation in China and India, 1986-2015. American Economic Journal: Applied Economics, 1(2), 53-63. https://doi.org/10.1257/app.1.2.53

Ramot, I. A. L. \& Ichihashi, M. (2012). The effect of tax structure on economic growth and income inequality. IDEC Discussion paper.

Sameti, M. \& Rafie, L. (2010). Interaction of income distribution, taxes and economic growth: The case of Iran and some selected East Asian countries. Iranian Economic Review, 14(25), 1-15.

TJNA \& Christian Aid (2014, July 5). Africa rising? Inequalities and the essential role of fair taxation. Retrieved from http://www.christianaid.org.uk./ net.

Wikipedia (2017). Retrieved from http:// www.en.wikipedia.org/net. 


\section{APPENDIX: REGRESSION ANALYSIS}

Dependent Variable: D(GINI)

Method: Least Squares

Date: 02/25/18 Time: 17:03

Sample (adjusted): 19952016

Included observations: 22 after adjustments

HAC standard errors \& covariance (Bartlett kernel, Newey-West fixed bandwidth $=3.0000$ )

\begin{tabular}{ccccc}
\hline Variable & Coefficient & Std. Error & t-Statistic & Prob. \\
\hline D(CIT) & $-1.56-08$ & $5.59-09$ & -2.788492 & 0.0131 \\
D(CED) & $9.19-08$ & $1.87-07$ & 0.492131 & 0.6293 \\
D(PPT) & $6.27-09$ & $1.35-09$ & 4.649113 & 0.0003 \\
D(VAT) & $2.13-08$ & $2.61-08$ & 0.818255 & 0.4252 \\
ECM(-1) & -0.916742 & 0.138696 & -6.609735 & 0.0000 \\
C & -0.001771 & 0.008005 & -0.221254 & 0.8277 \\
& & & & \\
R-squared & 0.508217 & Mean dependent var & 0.003636 \\
Adjusted R-squared & 0.354535 & S.D. dependent var & 0.050289 \\
S.E. of regression & 0.040403 & Akaike info criterion & -3.352837 \\
Sum squared resid & 0.026118 & Schwarz criterion & -3.055280 \\
Log likelihood & 42.88120 & Hannan-Quinn criter. & -3.282741 \\
F-statistic & 3.306940 & Durbin-Watson stat & 2.002926 \\
Prob(F-statistic) & 0.030632 & Wald F-statistic & 10.79974 \\
Prob(Wald F-statistic) & 0.000112 & &
\end{tabular}

Breusch-Godfrey Serial Correlation LM Test:

\begin{tabular}{cccc}
\hline F-statistic & 1.322248 & Prob. F(2,14) & 0.2979 \\
Obs*R-squared & 3.495385 & Prob. Chi-Square(2) & 0.1742 \\
\hline
\end{tabular}

Source: Eviews8.0 


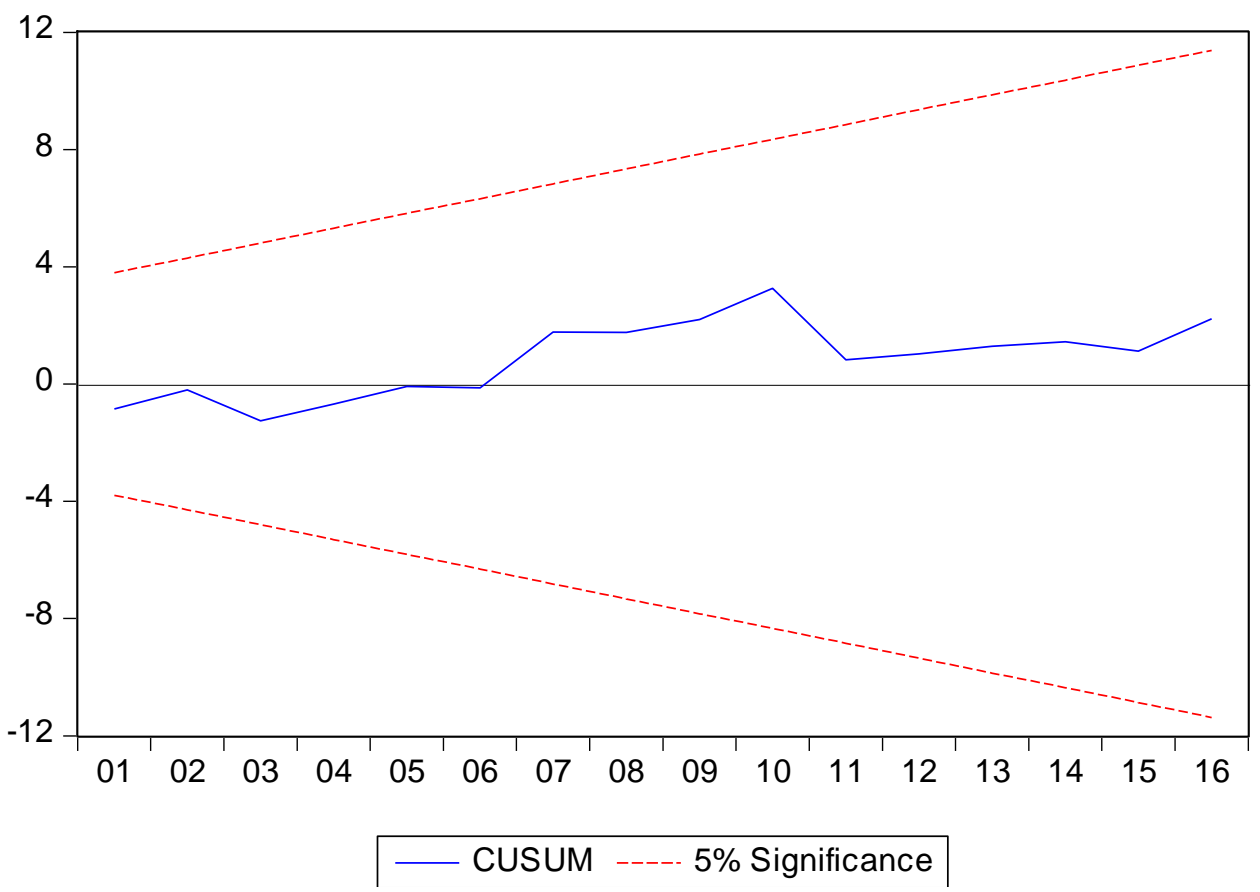

Ramsey RESET Test

Equation: UNTITLED

Specification: DGINI DPPT DVAT DCED DCIT C

Omitted Variables: Squares of fitted values

\begin{tabular}{cccc}
\hline & Value & Df & Probability \\
\hline t-statistic & 1.140268 & 15 & 0.2721 \\
F-statistic & 1.300211 & $(1,15)$ & 0.2721 \\
Likelihood ratio & 1.745685 & 1 & 0.1864
\end{tabular}

Source: Eviews8.0

\begin{tabular}{cccc}
\hline \multicolumn{4}{c}{ Heteroskedasticity Test: } \\
\hline Freusch-Pagan-Godfrey \\
\hline F-statistic & 0.202879 & Prob. F(5,16) & 0.9565 \\
Obs*R-squared & 1.311634 & Prob. Chi-Square(5) & 0.9337 \\
Scaled explained SS & 1.058615 & Prob. Chi-Square(5) & 0.9577
\end{tabular}

Source: Eviews8.0 